\title{
The European Union at a Crossroads
}

[SE blogs.Ise.ac.uk/eurocrisispress/2017/02/20/the-european-union-at-a-crossroads/

Eurocrisis in the

Press

By Roberto Orsi

The European Union is approaching a moment of difficult decisions which will determine whether it will manage to survive in the near future or whether it will enter the final trajectory of its dissolution. In the past few years a series of crises have shaken the very foundations of the European integration project, often with damage which clearly appears irreversible, particularly the ongoing migration crisis, Brexit, and the festering Eurozone crisis. Now a new chapter of the crisis in the common currency is rapidly becoming apparent. On the one hand, Greece is again dealing with financial trouble which would require another round of international intervention; talks of Grexit have re-gained momentum. On the other hand, and adding to that, the worsening of Italy's financial outlook is bringing about this time

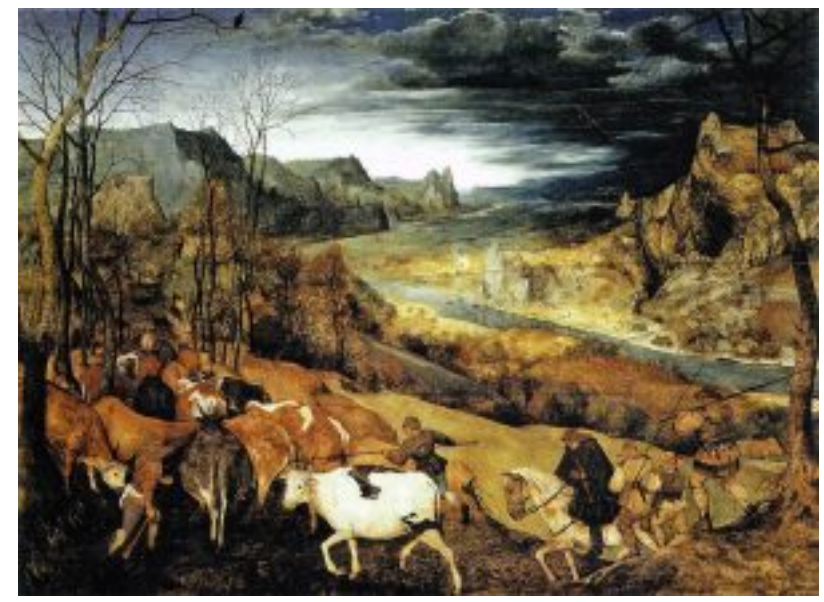
unavoidable and fundamental questions about the entire europroject and its future.

With Renzi's defeat in the referendum concerning constitutional reforms (November $4^{\text {th }}, 2016$ ) and the collapse of his government, political uncertainty has returned to Rome. However, this time it is not the stereotypical situation of Italian politics. A few things have become rather clear to all those who want to see them:

1. Italy's economy is not going to grow much faster than $1 \%$ per year in the foreseeable future in the best possible scenario. This comes after roughly twenty years of stagnation-depression. If Italy can only record a $0.9 \%$ growth in 2016, a year when numerous external circumstances were massively in its favour (a weak euro, ultra-low interest rates, quantitative easing from the ECB, low oil prices, growing trade partners), what will happen when this exceptional alignment of propitious planets dissolves?

2. Italy's chances of economic growth are hampered by a severely negative demography, a well-known problem which cannot be solved by additional immigration, particularly considering that many migrants have started to leave for more dynamic economies or more generous welfare systems, and hundreds of thousands of young Italians, often with high qualifications and skills, are leaving the country for good. Demography alone condemns the country to a near-zero or negative GDP growth, with all the financial implications.

3. A series of financial cracks have started to appear: not only the well-known story of MPS bank, but the banking sector in general is under pressure, with numerous institutions facing serious trouble. Unicredit, the largest bank in Italy, has closed 2016 with a loss of $€ 8$ billion, and it is now trying to raise an unprecedented $€ 13$ billion in new capital. Furthermore, it emerged recently that INPS, the largest state-owned pension fund and one of the largest in Europe, runs a deficit of over $€ 12$ billion/year and during 2016 has crossed the boundary into negative equity. Directly or indirectly, all these are deficits which will have their impact on the state budget, as candidly admitted by the INPS president.

4. Italy has a debt/GDP ratio of well over $130 \%$. With an economy which cannot grow in real terms, it can only reduce its debt burden by means of inflation. However, on the one hand the ECB has to keep inflation within limits in the interest of the Eurozone at large, and on the other higher inflation would push interests in the Italian debt higher, with a heavier interest burden which Italy cannot afford (if not financially, then certainly in political terms). After 2011-2012, when it became clear that markets were pushing Italy towards insolvency, the ECB has engineered a protection net to prop-up the national debt, thereby gaining time. However, this 
came as a consequence of a political agreement within the EU, according to which Italy received (indirect, but massive) financial aid in exchange for deep reforms of its economic system: from labour market laws to pensions, from spending cuts to governance changes. The German/EU idea was that Italy could be put back on the tracks of economic-financial sustainability through those reforms, which were even listed in all detail in a famous letter from the ECB in summer 2011.

5. After more than five years and three governments (Monti, Letta, Renzi) in which the technocrats of the economic ministries and the Bank of Italy have played an important role, it is clear that Italy is fundamentally unable to reform itself and therefore it will not regain the aforementioned economic and financial sustainability. In all frankness, the German/EU plan was hyper-optimistic at best, bordering on delusion.

6. As these elements become all too apparent, the political debate in Italy is becoming more disillusioned than ever about the immediate future of the country. What was once the twisted idea of some pessimist commentators, including the author of this piece, it is now becoming widely accepted: Italy will face a major financial shock, and state insolvency is now practically impossible to avoid within the current formulation of the euro-system. Hence the rise of a growing number of those who argue for exiting the Eurozone altogether, as well as a strong anti-EU and anti-German rhetoric.

Against this backdrop, the question for the EU is whether it will accept to prop-up the finances of Italy and Greece almost unconditionally in the future. In other words, whether the Eurozone will become a veritable and practically irreversible transfer union, where money is channelled, directly or indirectly (the latter is already happening), from sounder fiscal systems to cover the deficits of Rome and Athens, deficits which are created, among other things, in order to feed the clientelistic networks on which political consensus is based. The European partners may accept to do so, out of political, geopolitical, or even humanitarian considerations. Indeed given that Italy and Greece will probably never be back on a sustainable track, the only real alternative to a transfer union is them leaving the Eurozone. This would entail a further, massive political blow to the European project, as well as a wave of acute financial instability (Italy's national debt is well above the $€ 2.2$ trillion mark), in turn triggering further political and humanitarian problems downstream.

On the other hand, however, instituting a transfer union would go against the EU treaties (arguably, although that may somehow be circumvented by creative jurisprudential interpretation), the constitutions of numerous member states, particularly Germany, the will of many in the EU elite, and certainly of electorates. Angela Merkel has therefore already in the past re-stated that the position of the German government remains committed to rejecting the pooling of national debts (Eurobonds). However, as in the case of the migration crisis, Merkel's position may change and/or more probably, will result in a mix of delayed decisions and half-measures whereby in the end the Germans may well find themselves in a transfer union they never wanted, but which becomes "unavoidable", to be packaged by the media as a new national challenge in the name of solidarity (unlimited, unconditioned), and something to be proud of as well (Wir schaffen das!). This is not too probable, but also not impossible, as Germany's political system openly relies on the principle that "there is no alternative to Merkel", not exactly the mark of a wellfunctioning constitution.

Nevertheless, even if Germany may in the end accept a transfer union, it is extremely unlikely that other euro-states, such as for instance Finland, or the Netherlands, or Austria, will accept this arrangement, and will most certainly decide to opt out. At a deeper level, the Eurozone and the EU in general is rapidly turning into the opposite of what it was supposed to be at its inception a quarter of century ago. From a club of advanced economies and well-run states governed by the principles of Ordnungspolitik, fiscal integrity, and market oriented competition, it has turned into a redistribution system which accepts the failure of modernisation for vast areas of the continent, accommodates clientelistic if not kleptocratic elites in the South, and openly accepts economic parasitism, until the exhaustion of the relatively few, still productive economic centres in the North.

The question of the transfer union is a real and quite imminent crossroads for the EU. If the EU gives up on its core idea of modernisation, the euro-project can kick the can for another generation or so, at the price of being held 
together almost exclusively by negative forces, namely the fears of a complete break-up and the unwillingness to face its costs, and accepting the defection of several smaller economies in the North. Otherwise, no transfer union will mean the break-up of the Eurozone: initially involving Italy and Greece, with an extremely uncertain future for both countries, and almost certainly the successive disintegration of the rest (France's trajectory is in the long-run unsustainable, too).

Either way, the integrity of the Eurozone and its symbolic value may have to be jettisoned, with severe and difficult to control political implications. The recent talk about a multi-speed Europe by Merkel, echoing the idea of a split euro into smaller currency unions for more economically homogeneous areas, is no less ridden with formidable financial and political risks. It is not uncommon in history that last-minute reform attempts in a fragile structure can trigger uncontrollable events, as Gorbachev's reforms in the USSR did.

The EU used to be based on two pillars: the Schengen agreement, and the euro. Schengen is in tatters, the euro has not quite reached the goals it was supposed to achieve. With both pillars failing, and the almost impossible task of overcoming Brexit, the choice is now whether the EU will manage to survive as an institution almost by sheer bureaucratic inertia, or it be dismantled, whether in an orderly fashion or not.

Note: This article gives the views of the author, and not the position of the Euro Crisis in the Press blog nor of the London School of Economics.

Roberto Orsi is a co-investigator on the Euro Crisis in the Press project. He holds a PhD International Relations and is currently member of the Security Studies Unit at the Policy Alternatives Research Institute (東京大学政策ビ ジョン研究センター), and lecturer at the Graduate School of Public Policy (GraSPP - 東京大学公共政策大学院) of the University of Tokyo (Japan). His research interests focus on international political theory, history of ideas (particularly modern continental political philosophy and critical theory), political theology (Carl Schmitt). 